University of Nebraska - Lincoln

DigitalCommons@University of Nebraska - Lincoln

\title{
Nutritive Value of Rubber Seed (Hevea Brasiliensis) Meal: Utilization by Growing Pigs of Semipurified Diets in Which Rubber Seed Meal Partially Replaced Soybean Meal
}

\author{
G. M. Babatunde \\ University of Ibadan \\ W. G. Pond \\ Roman L. Hruska U.S. Meat Animal Research Center \\ E. R. Peo, Jr. \\ University of Nebraska-Lincoln
}

Follow this and additional works at: https://digitalcommons.unl.edu/animalscifacpub

Part of the Animal Sciences Commons

Babatunde, G. M.; Pond, W. G.; and Peo, Jr., E. R., "Nutritive Value of Rubber Seed (Hevea Brasiliensis) Meal: Utilization by Growing Pigs of Semipurified Diets in Which Rubber Seed Meal Partially Replaced Soybean Meal" (1990). Faculty Papers and Publications in Animal Science. 688.

https://digitalcommons.unl.edu/animalscifacpub/688

This Article is brought to you for free and open access by the Animal Science Department at DigitalCommons@University of Nebraska - Lincoln. It has been accepted for inclusion in Faculty Papers and Publications in Animal Science by an authorized administrator of DigitalCommons@University of Nebraska - Lincoln. 


\title{
NUTRITIVE VALUE OF RUBBER SEED (HEVEA BRASILIENSIS) MEAL: UTILIZATION BY GROWING PIGS OF SEMIPURIFIED DIETS IN WHICH RUBBER SEED MEAL PARTIALLY REPLACED SOYBEAN MEAL'
}

\author{
G. M. Babatunde ${ }^{2}$, W. G. Pond ${ }^{3}$ and E. R. Peo, Jr. \\ U.S. Department of Agriculture, Clay Center, NE 68933
}

\begin{abstract}
Thirty-six four-way cross (Chester White $\times$ Landrace $\times$ Large White $\times$ Yorkshire) growing barrows and gilts were used to investigate the effects of replacing graded levels of protein from soybean meal with equivalent levels of protein from rubber seed meal in $16 \% \mathrm{CP}$ semipurified diets on the performance characteristics, hematocrit, plasma metabolites and $\mathrm{N}$ utilization of pigs. The first diet (control) was largely comstarch-soybean meal in which the soybean meal supplied all of the CP. In other diets, nubber seed meal replaced $10 \%, 20 \%$ and $30 \%$, respectively, of the protein of soybean meal in the control diet. Twenty gilts were used in a $28-d$ growth trial and 16 barrows were used in an 8-d digestion trial (4-d collection). There were no differences $(P>.05)$ in ADG, ADF intake and in the feed:gain ratios, even though there was a trend for lower ADG and gain:feed ratio as the level of nubber seed meal increased in the diet. There were no differences in hematocrit, but plasma protein and albumin tended to be depressed when rubber seed meal provided more than $10 \%$ of the dietary protein. Apparent digestibilities of GE, DM and N were lower with rubber seed meal at $20 \%$ of the protein than with any other diet, but apparent $\mathrm{N}$ retained and the percent of digested $\mathrm{N}$ retained were not depressed significantly $(P>.05)$. Although rubber seed meal protein is of poorer quality than soybean meal protein for growing pigs, at least $10 \%$ of dietary protein can be provided by rubber seed meal without adversely affecting growth and $\mathrm{N}$ utilization.

(Key Words: Pigs, Rubber Seed Meal, Digestibility, Nitrogen Retention, Growth, Hevea brasiliensis.)
\end{abstract}

J. Anim Sci. 1990. 68:392-397

\section{Introduction}

Persistent shortages of the conventional feedstuffs for livestock feeding in the developing countries are caused largely by inadequate production of farm crops to meet the needs both of humans and of their domestic animals. This has forced animal nutritionists to intensify research into the feeding values of potentially useful but unconventional crop products. One of these is rubber seed meal obtained from rubber tree seed (Hevea brasiliensis). These seeds are very rich in oil and are produced in quantities of approximately $5 \mathrm{~kg} /$ tree annually (Bressani et al., 1983). If the oil, which is very rich in linolenic and linoleic acids (Babatunde and Pond, 1987b), can be extracted and used commercially for food and industrial markets, the cake may be used for 
TABLE 1. COMPOSITION OF DIETS

\begin{tabular}{|c|c|c|c|c|}
\hline Ingredients & Diet $1, \%$ & Diet $2, \%$ & Diet $3, \%$ & Diet $4, \%$ \\
\hline $\begin{array}{l}\text { Cornstarch } \\
\text { Soybean meal (44\% protein) } \\
\text { Rubber seed meal } \\
\text { Corn oil } \\
\text { Dicalcium phosphate } \\
\text { Limestone } \\
\text { Iodized salt } \\
\text { Vitamin premix } \\
\text { Mineral premix } \\
\text { Choline chloride }^{\mathrm{d}} \\
\text { Antioxidant } \\
\text { Total }\end{array}$ & $\begin{array}{r}54.84 \\
36.36 \\
\\
4.88 \\
2.40 \\
.50 \\
.40 \\
.20 \\
.20 \\
.20 \\
.02 \\
100.00\end{array}$ & $\begin{array}{r}54.44 \\
32.73 \\
5.65 \\
3.26 \\
2.40 \\
.50 \\
.40 \\
.20 \\
.20 \\
.20 \\
.02 \\
100.00\end{array}$ & $\begin{array}{r}54.05 \\
29.09 \\
11.31 \\
1.63 \\
2.40 \\
.50 \\
.40 \\
.20 \\
.20 \\
.20 \\
.02 \\
100.00\end{array}$ & $\begin{array}{r}53.67 \\
25.45 \\
16.96 \\
\\
2.40 \\
.50 \\
.40 \\
.20 \\
.20 \\
.20 \\
.02 \\
100.00\end{array}$ \\
\hline $\begin{array}{l}\text { Analyzed composition, } \% \\
\text { GE, kcal/kg } \\
\text { DM } \\
\text { CP } \\
\text { Cell contents } \\
\text { Cell walls } \\
\text { ADF } \\
\text { Cellulose } \\
\text { Lignin } \\
\text { Ca } \\
\text { P }\end{array}$ & $\begin{array}{r}4,441 \\
90.9 \\
14.8 \\
91.0 \\
9.0 \\
6.3 \\
5.3 \\
1.8 \\
.83 \\
.64\end{array}$ & $\begin{array}{c}4,391 \\
90.5 \\
15.7 \\
92.8 \\
7.2 \\
6.4 \\
5.3 \\
1.8 \\
.76 \\
.59\end{array}$ & $\begin{array}{c}4,396 \\
91.1 \\
17.4 \\
92.6 \\
7.4 \\
6.8 \\
5.2 \\
2.3 \\
.85 \\
.72\end{array}$ & $\begin{array}{r}4,468 \\
91.0 \\
18.5 \\
90.7 \\
9.3 \\
6.5 \\
5.6 \\
1.8 \\
.83 \\
.74\end{array}$ \\
\hline
\end{tabular}

Rubber seed meal, brought from Nigeria, contained $28.3 \%$ CP, $28.8 \%$ ether extract, $90.6 \%$ DM and 5.916 kcal GE/kg.

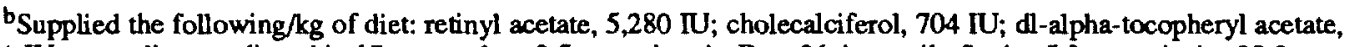
$70.4 \mathrm{IU}$; menadione sodium bisulfite complex, $3.5 \mathrm{mg}$; vitamin $\mathrm{B}_{12}, 26.4 \mu \mathrm{g}$; riboflavin, $5.3 \mathrm{mg}$; niacin, $28.2 \mathrm{mg}$; d-pantothenic acid, $21.1 \mathrm{mg}$; biotin, $88 \mu \mathrm{g}$; thiamin, $2.2 \mathrm{mg}$.

'Supplied the following in $\mathrm{mg} / \mathrm{kg}$ of diet: $\mathrm{Fe}$ (as $\mathrm{FeSO}_{4} \cdot 7 \mathrm{H}_{2} \mathrm{O}$ ), 160, $\mathrm{Cu}$ (as $\mathrm{CuO}$ ), 10, $\mathrm{Mn}$ (as $\mathrm{MnO}$ ), 20; $\mathrm{Zn}$ (as $\mathrm{ZnO}$ ), $100 ; \mathrm{CaCO}_{3}$ used as carrier.

'Supplied $868 \mathrm{mg}$ choline $/ \mathrm{kg}$ of diet.

'Santoquin, Monsanto Co., St. Louis, MO; provided 132 ppm ethoxyquin as an antioxidant

livestock feeding. Earlier attempts at characterizing the nutritive value of the rubber seed meal were made by Orok and Bowland (1974), Fetuga et al. (1977), Bressani et al. (1983) and Babatunde and Pond (1987a) with rats and by $\mathrm{Bu}$ vanendran and Siriwandene (1970), Yeong and Syed Ali (1979), Yeong et al. (1981) and Narahari and Kothandaraman (1984) with poultry. Only Rajaguru and Ravindran (1979) and Ong and Radem (1981) have concluded studies feeding rubber seed meal to pigs. The present work was done to determine the effects of incremental replacement of soybean meal with rubber seed meal in semipurified comstarch-soybean meal diets on growth, feed consumption, gain:feed ratio, hematocrit and plasma metabolites of growing pigs and on their energy and protein digestion and retention.

\section{Materlals and Methods}

Growth Studies. Twenty crossbred (Chester White $\times$ Landrace $\times$ Large White $\times$ Yorkshire) growing gilts weighing $22 \pm .5 \mathrm{~kg}$ body weight were randomly divided into four treatment groups of five pigs, each of which was penned individually. The limited supply of rubber seed meal available for the experiments precluded the use of more than five pigs/diet for a 4-wk growth experiment and four pigs/diet for the $\mathrm{N}$ balance and digestibility experiments. Pigs were assigned randomly to pens and dietary treatments and allowed ad libitum access to their assigned diet. All diets (Table 1) were calculated to contain $16 \% \mathrm{CP}$ and were similar in fat content. The control diet (Diet 1) contained soybean meal as the sole source of protein. Diets 2, 3 and 4 were formulated by replacing 10,20 and $30 \%$, respectively, 
TABLE 2. DAILY GAIN, DAILY FEED AND FEED:GAIN RATIO OF GROWING SWINE FED RUBBER SEED MEAL AS A PARTIAL SUBSTITUTE FOR SOYBEAN MEAL IN THE DIET"

\begin{tabular}{|c|c|c|c|c|c|c|c|}
\hline \multirow[b]{2}{*}{ Trait } & \multicolumn{4}{|c|}{ Diet SBM protein replaced by RSM protein, \% } & \multirow[b]{2}{*}{ SD } & \multicolumn{2}{|c|}{ Probability } \\
\hline & 0 & 10 & 20 & 30 & & Linear & Quadratic \\
\hline Daily gain, $\mathrm{g}$ & 586 & 518 & 470 & 496 & 91 & .12 & .25 \\
\hline Daily feed, $g$ & 1,408 & 1,368 & 1,360 & 1,302 & 197 & .89 & .92 \\
\hline Feed:gain & 2.43 & 2.65 & 2.93 & 2.67 & .429 & .14 & .23 \\
\hline
\end{tabular}

${ }^{\text {a}}$ Five pigs/treatment; average initial weight, $21.9 \mathrm{~kg} ; 28-\mathrm{d}$ experiment.

of the CP from the control diet with protein from rubber seed meal. Com oil was added to Diets 1 , 2 and 3 to equalize the calculated oil contents of the diets based on the residual oil content of the rubber seed meal $(28.8 \%)$ used in the study.

Individual body weight and feed consumption were recorded weekly for $28 \mathrm{~d}$. On d 28 , a blood sample was collected from the anterior vena cava of each pig for hematocrit and for plasma total protein, albumin and urea $\mathrm{N}$ determination.

Digestion Trial. Sixteen growing crossbred (Chester White $\times$ Landrace $\times$ Large White $\times$ Yorkshire) barrows were divided randomly into four groups of four barrows (initial weight, 22 $\mathrm{kg}$ ). Each group of four pigs was sub-divided into two replicate pairs of pigs and fed the same diets used for the growth trial. Only eight pigs could be accommodated conveniently in the metabolism cages, so two replicate studies were conducted sequentially. Weighed quantities of feed, approximately $2.3 \%$ of $B W / d$, were given to each pig daily throughout the 4-d adjustment and 4-d fecal collection periods. Feed offered was restricted to minimize potential effects of level of feed intake on endogenous nutrient losses. Pigs fed $30 \%$ rubber and seed meal failed to consume all of their daily ration during the first $2 \mathrm{~d}$, so their daily intake was reduced to $1.7 \%$ of $\mathrm{BW}$. The urine was collected in plastic bottles containing a fixed quantity $(10 \mathrm{ml})$ of $1 \mathrm{~N} \mathrm{HCl}$ to preserve the urine and minimize $\mathrm{NH}_{3}$ loss. Total feces were collected daily and immediately frozen for the 4-d collection. Total fecal outputs for each pig for the $4 \mathrm{~d}$ were bulked, mixed and dried to constant weight in a draft oven at $60^{\circ} \mathrm{C}$ for $3 \mathrm{~d}$.

\footnotetext{
${ }^{5}$ Technicon Auto N Analyzer, Technicon, Inc., Tarrytown, NY.
}

Composites then were ground in a small hammer mill and bottled, and samples were taken for adiabatic bomb calorimetry and $\mathrm{N}$ determination. Urine was thawed and diluted with water to a constant volume from which 100 -ml aliquots were taken and stored for subsequent analysis. Nitrogen was determined on the urine samples using an autoanalyzer. The determined values for DM, N and GE in feces and feeds and $\mathrm{N}$ in urine were used to calculate apparent digestibility, apparent $\mathrm{N}$ retention and percentages of digested $\mathrm{N}$ retained by the pigs fed each diet.

Data were subjected to the SAS least squares means analysis of variance (SAS, 1979) by the General Linear Models procedure. Individual animal was the experimental unit. Linear and quadratic effects of incremental rubber seed meal substitution in the diet were tested by regression analysis.

\section{Results}

Table 2 shows the effect of incremental replacement of soybean meal protein with rubber seed meal protein on daily weight gain, feed consumption and feed:gain ratio of growing pigs. Replacement of up to $30 \%$ of the soybean meal protein with rubber seed meal protein did not affect $(P>.05)$ ADG, feed intake or feed:gain ratio of the pigs, although performance tended to decline (linear effect at $P<.12$ ) as the level of rubber seed meal increased.

Hematocrit, total plasma protein, plasma albu$\mathrm{min}$, and plasma urea analytical results are summarized in Table 3 . There were no significant differences in hematocrit, although it tended to decrease (linear effect at $P<.18$ ) as the level of rubber seed meal protein increased. Plasma total protein and plasma albumin tended to be depressed by increasing levels of rubber seed meal protein, but the differences were not significant 
(linear effects of $P<.57$ and $P<.46$, respectively). Plasma urea tended to increase as the level of rubber seed meal increased, except for pigs fed $20 \%$ rubber seed meal protein, in which values were similar to those of pigs fed the control diet.

The apparent digestibilities of energy $(P<.04), \mathrm{DM}(P<.07)$ and $N(P<.050)$ all were reduced by providing $20 \%$ of the dietary protein in the diet as rubber seed meal (Table 4), but values for $30 \%$ rubber seed meal protein were similar to those of controls, resulting in significant linear $(P<.03)$ and quadratic $(P<.03)$ effects for each trait. There were no treatment effects on apparent $\mathrm{N}$ retained and the percent of digested $\mathrm{N}$ retained $(P>.05)$, although values tended to decline as the level of rubber seed meal increased.

\section{Discussion}

The responses in pig performance to increasing levels of rubber seed meal protein are similar to those of Babatunde and Pond (1987a) with rats. The present results agree with those of Rajaguru and Ravindran (1979), who obtained a significant depression in performance with greater than $10 \%$ substitution of soybean meal with rubber seed meal in swine diets. Ong and Radem (1981) found no such depression as a result of replacing soybean meal with rubber seed meal, but they included fishmeal in the diets at $8 \%$ for growing pigs and $4 \%$ for fattening pigs. Rajaguru and Ravindran (1979) attributed the poor performance of pigs fed high levels of rubber seed meal to an amino acid imbalance. Orok and Bowland (1974), Fetuga et al. (1977) and Babatunde and Pond (1987a) demonstrated with rats that the primary problem with rubber seed meal protein was its low lysine content. Methionine content of rubber seed meal was found to be close to that of soybean meal, although the total sulfur amino acid content was lower than of soybean meal.

The possibility that $\mathrm{HCN}$ is responsible for the depression in performance was dispelled by Ong and Radem (1981) and Babatunde and Pond (1987a), who found only very low residual concentrations of $\mathrm{HCN}$ in their nubber seed meal samples.

The tendency for a reduction in hematocrit with increased rubber seed meal in the diet agrees with earlier work (Babatunde and Pond, 1987a) in which dark brown urine coloration with high bilirubin content was observed in rats; this presumably reflected red blood cell destruction by 


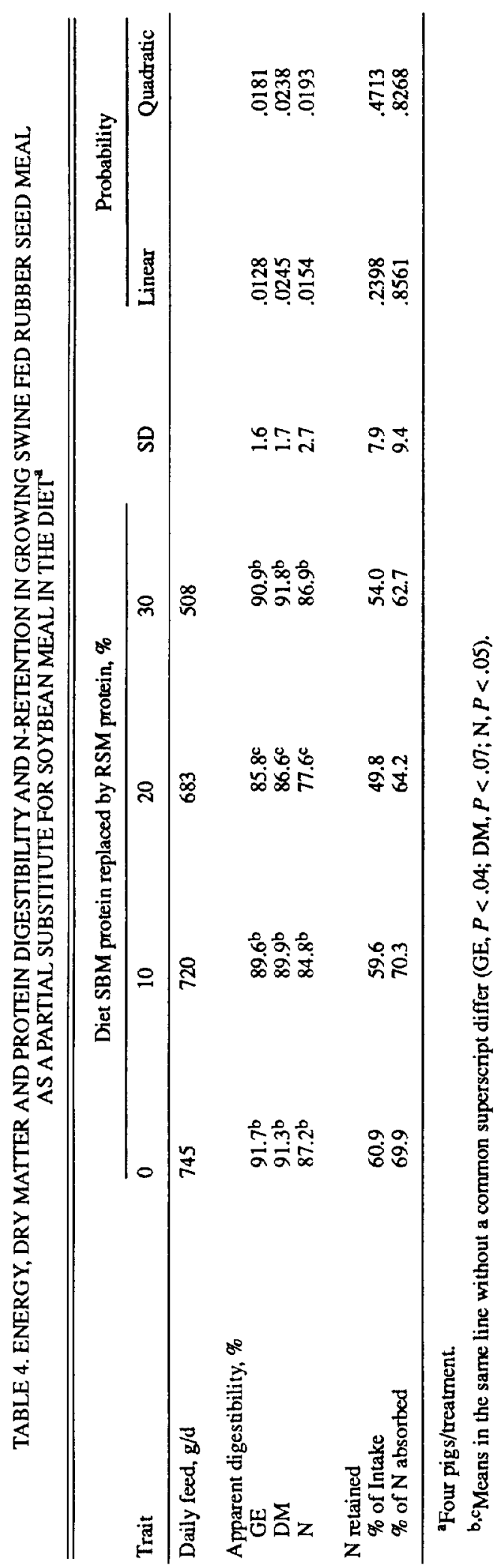

some unidentified factor present in the rubber seed meal. The trend for reductions in total plasma protein and plasma albumin and the increase in plasma urea $\mathrm{N}$, all of which are recognized as indicators of poor dietary protein quality (Kumta and Harper, 1961; Eggum, 1970; Lewis et al., 1977), with increasing level of rubber seed meal in the diets also agrees with the findings by Babatunde and Pond (1987a) with rats. Babatunde and Pond (1987a) showed that the supplementation of the rubber seed meal diet with lysine increased total plasma protein and plasma albumin and reduced plasma urea to levels comparable to those of the rats fed the control soybean meal diet.

Trends for declines in DM, energy and $\mathrm{N}$ digestibility and retention were apparent except for pigs fed $30 \%$ rubber seed meal protein. Animals fed $30 \%$ rubber seed meal protein at first failed to consume their allotment, so intake was reduced. The reduction in digestibilities of DM, $\mathrm{N}$ and energy in pigs fed rubber seed meal at $20 \%$ of dietary protein may have been due to lower true digestibility of the protein in rubber seed meal or to the presence of one or more inhibitors of proteolytic enzymes, similar to those present in raw soybeans. Higher fiber content of rubber seed meal than of soybean meal has been reported (Ong and Yeong, 1978; Narshari and Kothandaraman, 1984), but analytical values for mixed diets used in the present work do not suggest that this is a factor in nutrient digestibility. A possible explanation for the depressed $\mathrm{N}$ retention in pigs fed rubber seed meal at $20 \%$ of dietary protein is that lysine deficiency impaired the utilization of absorbed N. Orok and Bowland (1974) obtained similar nonsignificant depressions in $\mathrm{N}$ retention in rats as rubber seed meal level increased. In rats, the depression in $\mathrm{N}$ retention associated with increased rubber seed meal in the diet was reversed by supplementation of the rubber seed meal diet with lysine, but added lysine did not improve N, DM or energy digestibility (G. M. Babatunde and W. G. Pond, unpublished data).

Based on performance characteristics as the sole criterion to evaluate the effects of replacing soybean meal protein with rubber seed meal protein, the maximum substitution compatible with normal performance is equal to or greater than $30 \%$ of the protein in the diet, but to maintain normal levels of plasma metabolites and avoid depressed nutrient digestibility and retention, the maximum replacement level is $10 \%$ in cornstarch-soybean meal semipurified diets for growing pigs. 


\section{Impllcations}

Rubber seed meal can be used to provide up to $10 \%$ of the dietary protein without adversely affecting BW gain or N utilization. Rubber seed meal may be used as a partial replacement for higher-quality protein sources in the diets of swine. This under-utilized product may be a valuable protein source for swine produced in areas where rubber seed meal is readily available.

\section{Uterature Clted}

Babatunde, G. M. and W. P. Pond. 1987a. Nutritive value of rubber seed (Hevea brasiliensis) meal and oil. I. Rubber seed meal versus soybean meal as sources of protein in semipurified diets for rats. Nutr. Rep. Int 36:617.

Babatunde, G. M. and W. G. Pond. 1987b. Nutritive value of rubber seed (Hevea brasiliensis) meal and oil. II. Rubber seed oil versus corn oil in semipurified diets for rats. Nutr. Rep. Int. 36:857.

Bressani, R., L. G. Elias, J. Ayuso, O. Rosal, J. E. Braham and J. Zuniga. 1983. Nutritive value of protein and oil in rubber seed (Hevea brasiliensis). Turrialba 33:61.

Buvanendran, V. and J. A. Des Siriwandene. 1970. Rubber seed meal in poultry diets. Ceylon Vet. J. 18:33.

Eggum, B. O. 1970. Blood urea measurements as a technique for assessing protein quality. J. Nutr. 24:983.

Fetuga, B. L., J. O. Ayeni, A. Olaniyan, M. A. Balogun, G. M. Babatunde and V. A. Oyenuga. 1977. Biological evaluation of para-rubber seeds (Hevea brasiliensis). Nutr. Rep. Int 15:497.

Kumta, U. S. and A. E. Harper. 1961. Amino acid imbalance. VII. Effects of dietary additions of amino acids on food intake and blood urea concentration of rats fed low protein diets containing fibrin. J. Nutr. 74: 139.

Lewis, A. J., E. R. Peo, Jr., P. J. Cunningham and B. D. Moser. 1977. Determination of optimum dietary proportions of lysine and tryptophan for growing rats based on growth, food intake and plasma metabolites. J. Nutr. 107:1361.

Narahari, D. and P. Kothandaraman. 1984. Chemical composition and nutritional value of para-rubber seed and its products for chickens. Anim. Feed Sci. Technol. 10:257.

Ong, H. K. and J. Radem. 1981. Effect of feeding rubber seed meal-based diets on performance and serum thiocyanate level of growing-finishing pigs. MARDI Res. Bull. 9:78.

Ong, H. K. and S. W. Yeong. 1978. Prospects for the use of rubber seed meal for feeding swine and poultry. In: D. Devendra and R. I. Hutagalung (Ed.) Feeding Stuffs for Livestock in South East Asia. pp 337-344. Malays. Soc. Anim. Prod., Malaysia.

Orok, E. J. and J. P. Bowland. 1974. Nigerian para-rubber seed meal as an energy and protein source for rats fed soybean meal or peanut meal-supplemented diets. Can. J. Anim. Sci. 54:239.

Rajaguru, A.S.B. and V. Ravindran. 1979. Rubber seed meal as a protein supplement in growing swine rations. J. Natl. Sci. Council of Sri Lanka 7(2):101.

SAS, 1979. SAS User's Guide: Statistics. SAS Institute, Inc., Cary, NC.

Yeong, S. W. and A. B. Syed Ali. 1979. The use of rubber seed meal in poultry. I. The effect of varying levels of rubber seed meal in broiler diets. MARDI Res. Bull. 7:127.

Yeong, S. W., A. B. Syed Ali and N. Yusof. 1981. The use of rubber seed meal in poultry. II. The effect of rubber seed meal in layers diets. MARDI Res. Bull. 9:92. 